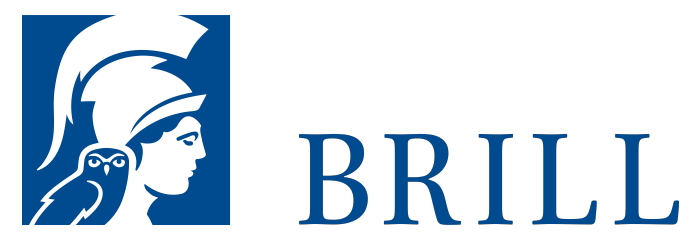

\title{
Intuitionen in der Ethik
}

\author{
3. Auflage
}

Author: Anne Burkard

Wenn wir in der philosophischen Ethik oder auch im Alltag moralische Urteile fällen, meinen wir, wenigstens in einigen dieser Urteile gerechtfertigt zu sein. Doch wie ist moralische Rechtfertigung möglich? So genannte >intuitionistische Theorien< wollen auf diese Frage eine Antwort geben. Der Kerngedanke intuitionistischer Ansätze besagt, dass unseren moralischen Intuitionen - verstanden als nicht abgeleitete moralische Urteile - eine legitime und unverzichtbare Rolle bei der moralischen Rechtfertigung zukommt. In der vorliegenden Studie werden intuitionistische Ansätze in verschiedenen, gegenwärtig prominenten Spielarten vorgestellt und einer systematischen Bewertung unterzogen. Die Autorin zeigt, dass die Ablehnung jeglicher Rückgriffe auf moralische Intuitionen unweigerlich zu einer radikalen Form der Moralskepsis führt. Zudem argumentiert sie dafür, dass zumindest einige gemäßigte Varianten des Intuitionismus in der Lage sind, den vielfältigen Herausforderungen zu begegnen, mit denen dieser sich konfrontiert sieht.

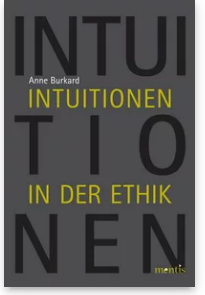

Pages: 333

Seiten

Language:

German

Subjects:

General,

Philosophy

Publisher: Brill | mentis

E-Book (PDF)

Released online:

O5 Sep 2012

ISBN: 978-3-

95743-957-4

List price

USD $\$ 63.00$

Paperback

Publication date: O5 Sep 2012

ISBN: $978-3-$

89785-792-6

List price

USD \$63.0o 
For more information see brill.com

Order information: Order online at brill.com +44330 333 0049 | customerservices@brill.com Submission information: brill.com/authors

Titles published by Brill | Fink, Brill | mentis or Brill | Schöningh: +49(o)715413279216| brill@brocom.de 